\title{
Quaternary glaciolacustrine deposits around a Triple Junction site: Paleolakes at the foot of the Northern Patagonian Ice field (Argentina and Chile)
}

\author{
*Federico Ignacio Isla ${ }^{1}$, Marcela Espinosa ${ }^{1}$
}

\begin{abstract}
1 Instituto de Geología de Costas y del Cuaternario (UNMDP-CIC), Instituto de Investigaciones Marinas y Costeras (UNMDPCONICET), Funes 3350, Mar del Plata.

fisla@mdp.edu.ar; maespin@mdp.edu.ar
\end{abstract}

*Corresponding author: fisla@mdp.edu.ar

\begin{abstract}
The area involved by the triple junction between the South American, Nazca and Antarctic plates activity was affected by Quaternary glaciations. Before 12,800 yrs BP an extended ice field occupied the top of the Patagonian Andes, irradiating glaciers towards the east and the west dominantly. Towards the east, the ice melted in piedmont lakes; towards the west, fjords melted into the Pacific Ocean. The Upper-Pleistocene climate amelioration caused the recession of those glaciers. Some piedmont lakes reversed their Atlantic outflow towards to the Pacific Ocean. The glaciers retreat caused the fluvial reactivations along crustal former faults that were located below the ice. The Patagonian ice field became therefore split into present Northern and Southern fields. At the second largest lake of South America, the Buenos Aires-General Carrera Lake, the water level dropped from about $500 \mathrm{~m}$ over present mean sea level to $230 \mathrm{~m}$. Several glaciolacustrine deposits from this area are indicating significant variations caused by climatic changes, volcanism and tectonics, differing in spatial and temporal magnitudes. The triple junction activity involved subduction of the Chile Ridge below the continental South American plate, volcanic activity and faulting. During the glacier melting the Baker River captured three eastern-moving glacial systems towards the southwest, towards the Pacific Ocean. This rapid event is thought to occur 12,800 yrs BP. The lowering of these glaciolacustrine systems should be also interpreted in terms of the tectonic activity in the region and considering other processes operating in the lakes and within the watersheds.
\end{abstract}

Keywords: Glaciolacustrine deposits, Triple junction, Northern Patagonian Ice Field, Argentina, Chile.

RESUMEN. Depósitos glacilacustres alrededor de una zona de triple unión: paleolagos al pie del Campo de Hielo Patagónico Norte. El área comprendida por el punto triple entre las placas Sudamericana, Nazca y Antártica fue afectada por glaciaciones durante el Cuaternario. Con anterioridad a los 12.800 años AP, un extenso campo de hielo ocupaba la cima de los Andes Patagónicos irradiando glaciares hacia el este y oeste dominantemente. Hacia el este el hielo se derretía en lagos pedemontanos; hacia el oeste los fiordos se internaban en el Océano Pacífico. El mejoramiento del clima durante el Pleistoceno Superior causó la recesión de esos glaciares. Algunos lagos pedementanos revirtieron su drenaje hacia el Atlántico y comenzaron a fluir hacia el Océano Pacífico. Este retroceso de los glaciares causó reactivaciones fluviales a lo largo de antiguas fallas que se ubicaban por debajo del hielo. El Campo de Hielo Patagónico se dividió entre los actuales Campo Norte y Campo Sur. En el segundo lago más grande de Sudamérica, el lago Buenos Aires-General Carrera, el nivel del agua descendió desde aproximadamente 500 a $230 \mathrm{~m}$ sobre el nivel medio del mar. Depósitos glacilacustres de esta área están indicando variaciones significativas causadas por cambios climáticos, volcánicos y tectónicos, diferenciándose en las magnitudes espaciales y temporales. La actividad de la zona de unión triple conlleva la subducción de la Dorsal de Chile por debajo de la placa continental Sudamericana, actividad volcánica y fallamiento. Durante el derretimiento de los glaciares el Río Baker capturó tres sistemas glaciarios moviéndose hacia el este y que ahora fluyen hacia el sudoeste, hacia el Océano Pacífico. Este evento rápido ocurrió hace 12,800 años AP. La disminución en altura de estos sistemas glacilacustres debe también interpretarse en relación a la actividad tectónica de la región considerando también otros procesos que intervienen en los lagos y en las cuencas. 


\section{Introduction}

During the Quaternary, climatic changes affected both hemispheres although they were not simultaneous and with the same magnitudes (Kaplan et al., 2004). The question remains whether these changes occurred gradually or abruptly (Broecker, 1998), or if the Holocene glacial advances occurred worldwide and simultaneously (Douglass et al., 2005). The behavior of glaciers is today matter of significant concern in relation to their effects on the present sea-level rise (Zemp et al., 2019). In the last years several reports have focused on the evolution of Quaternary lakes in relation to the Patagonian ice field (Ton-That et al., 1999; Kaplan et al., 2004; McCulloch et al., 2005; Hein et al., 2009, 2010; Horta et al., 2011, 2017; Van Daele et al., 2016; Bendle et al., 2017; Thorndycraft et al., 2019; Bourgois et al., 2019; Clague et al., 2020), presently divided into the Northern Ice Field (attached to the San Valentín Ice Field) and the Southern Ice
Field (Fig. 1). Caldenius (1932) first reported several glaciolacustrine records perched at different valleys at the foot of the Patagonian Andes. At the Epuyén paleolake $\left(40^{\circ} \mathrm{S}\right)$ he counted 240 varves. At the southern slope of the Nahuel Pan Mountain, close to the Corintos River, 1,089 varves were analyzed in a sequence of $78 \mathrm{~m}$ (Beraza and Vilas, 1990). At the eastern side of the General Carrera-Buenos Aires Lake, 530 varves were also discriminated (Caldenius, 1932) and seven delta fans were reported perched its southern margin (Bell, 2009).

Significant changes in the watersheds of the lakes of Patagonia and Tierra del Fuego have been reported (Ton-That et al., 1999; Kaplan et al., 2004; McCulloch et al., 2000, 2005; Del Valle et al., 2007; Solari et al., 2012: Horta et al., 2017; Bendle et al., 2017; Thorndycraft et al., 2019; Bourgois et $a l ., 2019)$. Concerning the Patagonian Ice Field, it became divided about 12,800 years ago (Turner et al., 2005). This caused a reversal in the direction of the

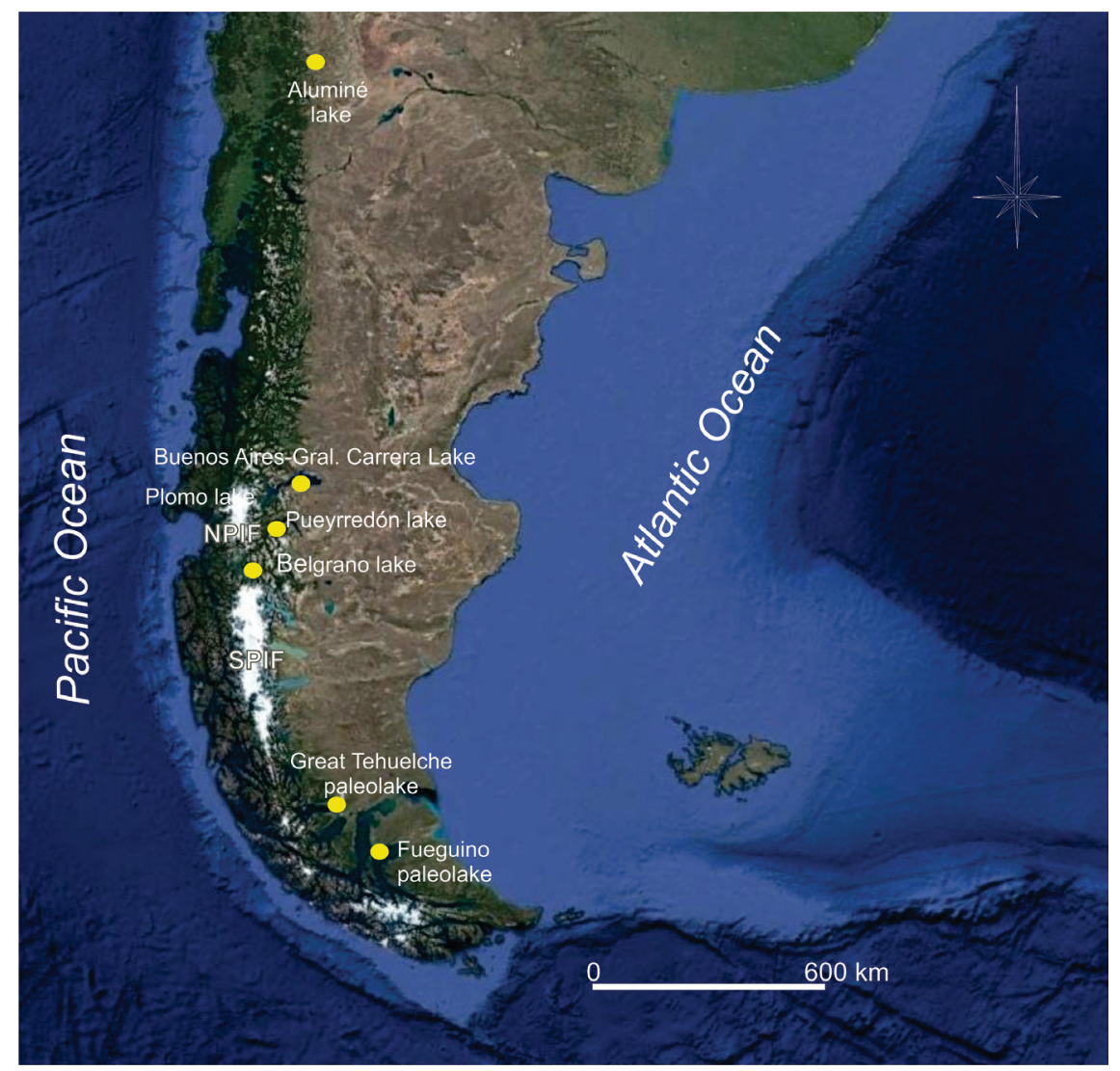

FIG. 1. Location of the lacustrine complexes mentioned in the text. NPIF: Northern Patagonian Ice Field; SPIF: Southern Patagonian Ice Field. 
drainage of two different lake complexes: the Buenos Aires-General Carrera, and the Pueyrredon-PosadasCochrane, with deactivations and activations of some river valleys (Isla et al., 2015; Glasser et al., 2016). Jökulhlaups events would have taken place during the evolution of some these lakes (Turner et al., 2005). Two glacier readvances were proposed to occur at this region $c a$. 8,200 and 6,200 yrs BP and assigned to a northward migration of the Southern Westerlies (Douglass et al., 2005). Many authors interpreted the geomorphological variations in particular areas of the Patagonian Andes in terms of climatic changes (Kaplan et al., 2004; McCulloch et al., 2005; Hein et al., 2009, 2010; Horta et al., 2011, 2017; Bendle et al., 2017; Thorndycraft et al., 2019; Bourgois et al., 2019). However, many changes could be also triggered by tectonic and volcanic activities associated to the dynamics of the triple junction site at the pacific coast in Patagonia (Lagabrielle et al., 2010; Georgieva et al., 2016), that migrated significantly from south to north since the Miocene (ca. $15 \mathrm{Ma}$ ).

This work comprises the description of glaciolacustrine deposits corresponding to Upper Pleistocene lakes that include the Buenos Aires-General Carrera, Bertrand, Plomo, Posadas, Pueyrredon and Cochrane lakes (Fig. 1). It has been assumed that both glacial valleys were occupied by a single and extensive lake named Chalenko Lake (Thorndycraft et al., 2019; Bourgois et al., 2019), although ice-walled lakes at different water levels could have existed (Martinod et al., 2016). The altitudes of these deposits were measured and analyzed in order to estimate the maximum altitude of these ancient paleolakes, and their lowering to present lakes. The particular evolution of these lakes in relation to the Triple Junction dynamics is compared to other piedmont lakes that had also significant changes in their watersheds at Patagonia and Tierra del Fuego.

\section{Geological setting}

The Buenos Aires-General Carrera Lake is the second largest lake in South America. It is occupying a glacial valley oriented $\mathrm{W}$ to $\mathrm{E}$ across the Patagonian Andes Cordillera where several Quaternary glaciations have occurred (Ton-That et al., 1999; Hein et al., 2009; Lagabrielle et al., 2010). The orientation of these lakes parallel to the dominant westerly winds causes seiches, mainly at the Argentine sector where the regional topography is not an obstacle to the wind action (Isla et al., 2010; Richter et al., 2010). At the southern shore of the General Carrera-Buenos Aires Lake, the Las Dunas River has built seven Gilberttype deltas (Bell, 2009). The oldest is at $650 \mathrm{~m}$ over present sea level (MSL) and assumed to be constructed ca. 13,000 years ago. The youngest non-operative delta (second delta) was probably constructed 8,500 years ago. The present delta is assumed to be stable at an altitude of $201 \mathrm{~m}$ for the last 6,200 years (Bell, 2009). The altitudes of these delta terraces above MSL along the General Carrera-Buenos Aires Lake shoreline were analyzed to discern its evolution (Bourgois et al., 2016) although their interpretations are not so simple (Martinod et al., 2016). An ice cover persisted in General Carrera- Buenos Aires Lake area until at least $16,934 \pm 116$ cal yrs BP (Bendle et al., 2017). Moraine successions corresponding to the maximum glacier extensions (23,000 yrs BP; Fénix V Moraine) were established either for the General Carrera-Buenos Aires (Kaplan et al., 2004) and Pueyrredon-Posadas-Salitroso-Ghio lakes (Hein et al., 2010). Between 16,000 and 15,600 years BP, the Chacabuco valley, located between General CarreraBuenos Aires and Pueyrredon-Posadas valleys, was reported free of ice and colonized by herbs, shrubs and evergreen forests (Villa-Martínez et al., 2012).

This lake complex is surrounded by basaltic rocks of Miocene-Pliocene ages (Meseta del Lago Buenos Aires Plateau; Panza and Nullo, 1994; Lagabrielle et al., 2010). The volcanic activity in this area remained until Pleistocene (Mazzoni and Rabassa, 2010; Ghiglione et al., 2016), with ash layers interfingered with glacial moraines (Fidalgo and Riggi, 1965; Ton-That et al., 1999; Kaplan et al., 2004), and with several intrusions of different basaltic dykes, as lopolites or laccolites (Lagabrielle et al., 2010) that could have caused local variations of the topographic altitudes. The recent alkaline volcanic activity $(<14 \mathrm{Ma})$ is related to Chile Ridge subduction at the Taitao Peninsula (Guivel et al., 1999; Lagabrielle et al., 2000, 2004). This particular case is a Ridge-Trench-Trench (RTT) junction dominated by horizontal displacements and produces tilting of crustal blocks along a network of strike-slip faults on the upper plate (Lagabrielle et al., 2000, 2010). The northward migration of the Triple Junction along this active margin has caused a bimodal composition of volcanic rocks: mafic to intermediate lavas $\left(48-56 \% \mathrm{SiO}_{2}\right)$ and acidic lavas ranging from dacites to rhyolites $\left(66-73 \% \mathrm{SiO}_{2}\right.$; 
Lagabrielle et al., 2000). After 3 Ma a tectonic crisis led to the general uplift of the piedmont areas in the eastern side of the Andes and the rapid subsidence of narrow transverse (E-W) valleys that were later occupied by the piedmont lakes (General CarreraBuenos Aires, and Cochrane-Pueyrredon-Posadas; Lagabrielle et al., 2010). The oblique subduction of the Chile Ridge caused the migration of the triple junction site from south to north up to the present location at latitude $46^{\circ} 30^{\prime} \mathrm{S}$ (Folguera and Ramos, 2002; Lagabrielle et al., 2010; Russo et al., 2010). The opening of an astenospheric window produced the dynamic uplift of the retroarc migrating from the piedmonts to the Extra Andean Patagonia (Lagabrielle et al., 2010; Georgieva et al., 2016) causing a tectonic crisis for the last $3 \mathrm{Ma}$ (Lagabrielle et al., 2010). This uplifting trend migrated northwards as the Chile Ridge subducted below South American Plate (Ghiglione et al., 2016). The relative motion between South American and Nazca plates was calculated about $8.5 \mathrm{~cm} / \mathrm{yr}$, and $2 \mathrm{~cm} / \mathrm{yr}$ between South American and the Antarctic plates (Boutonnet et al., 2010). The northward movement is caused by the asymmetric growing of this active ridge, even the architecture of the continental margin is different to the north and south of the present triple junction. To the north, the continental margin is characterized by a small, Plio-Quaternary, accretionary prism with much of the older material removed by tectonic erosion (Bourgois et al., 2000).
To the south, the accretionary prism widens abruptly as the deformation front migrated seawards and a broader zone of trench turbidites is involved in the deformation (Ranero et al., 2006). Considering the magnitudes of these tectonic effects in the region, the rol of the glacio-isostatic rebounds have been overestimated.

\section{Methods}

Glaciolacustrine deposits identified from field mapping were located on a GIS database (Arc View). Heights of the tops of these deposits were established with a handled GPS in order to recognize the deposits corresponding to the highest levels of the former lakes (Table 1). Radiocarbon dates are reported in the original units, either calibrated or without calibration (Table 2). The thicknesses of these sedimentary sequences were measured in each location. Seven samples from these glaciolacustrine deposits were analyzed for grain sizes distribution, combining sieving and the pipette methods. Sieving was performed every 0.5 phi units, from coarse to very fine sand. Results are reported in a triangle plot with the sand, silt and clay percentages. Altitudes were referred to mean sea level (MSL) avoiding estimations to the present level of the lakes, as these large lakes, oriented W-E, are subject to differences of several meters due to barometric-triggered seiches and wind effects (Richter et al., 2010).

TABLE 1. GEOGRAPHIC COORDINATES AND MAXIMUM ALTITUDES OF THE GLACIOLACUSTRINE SEQUENCES. LOCATIONS IN FIGURE 2.

\begin{tabular}{|c|c|c|c|c|}
\hline & Locality & Lat. $S$ & Long. W & $\begin{array}{c}\text { Altitude (m) } \\
\text { above MSL }\end{array}$ \\
\hline 1 & Fenix Chico & $46^{\circ} 25^{\prime} 49^{\prime \prime}$ & $70^{\circ} 44^{\prime} 27^{\prime \prime}$ & 460 \\
\hline 2 & Buenos Aires Lake & $46^{\circ} 34^{\prime} 26^{\prime \prime}$ & $71^{\circ} 03^{\prime} 44^{\prime \prime}$ & 354 \\
\hline 3 & 41 Route & $46^{\circ} 39^{\prime} 27^{\prime \prime}$ & $71^{\circ} 36^{\prime} 51^{\prime \prime}$ & 514 \\
\hline 4 & Jeinimeni & $46^{\circ} 34^{\prime} 27^{\prime \prime}$ & $71^{\circ} 39^{\prime} 35^{\prime \prime}$ & 262 \\
\hline 5 & Fachinal & $46^{\circ} 34^{\prime} 29^{\prime \prime}$ & $72^{\circ} 14^{\prime} 18^{\prime \prime}$ & 304 \\
\hline- & El Furioso & $46^{\circ} 46^{\prime} 01^{\prime \prime}$ & $72^{\circ} 35^{\prime} 26^{\prime \prime}$ & 332 \\
\hline 6 & Puerto Bertrand & $47^{\circ} 02^{\prime} 08^{\prime \prime}$ & $72^{\circ} 49^{\prime} 21^{\prime \prime}$ & 236 \\
\hline 7 & Borde Baker & $47^{\circ} 05^{\prime} 13^{\prime \prime}$ & $72^{\circ} 46^{\prime} 41^{\prime \prime}$ & 230 \\
\hline 8 & Chacabuco Bridge & $47^{\circ} 06^{\prime} 52^{\prime \prime}$ & $72^{\circ} 36^{\prime} 49^{\prime \prime}$ & 172 \\
\hline- & $38 \mathrm{~km} \mathrm{~S}$ Cochrane & $47^{\circ} 29^{\prime} 37^{\prime \prime}$ & $72^{\circ} 48^{\prime} 38^{\prime \prime}$ & 425 \\
\hline- & Deseado Terrace & $46^{\circ} 33^{\prime} 41^{\prime \prime}$ & $70^{\circ} 53^{\prime} 18^{\prime \prime}$ & 460 \\
\hline
\end{tabular}


TABLE 2. RADIOCARBON DATES CONSIDERED IN THIS PAPER.

\begin{tabular}{lccl}
\hline \multicolumn{1}{c}{ Location } & ${ }^{14} \mathbf{C}$ yrs BP & Cal yrs BP $(\mathbf{2} \boldsymbol{\sigma})$ & \multicolumn{1}{c}{ References } \\
\hline General Carrera Lake & $6,200 \pm 80$ & 7,082 & Bell, 2009 \\
General Carrera Lake & $8,500 \pm 70$ & 9,481 & Bell, 2009 \\
General Carrera Lake & $11,200 \pm 150$ & 12,714 & Bell, 2009 \\
Buenos Aires Lake & $16,934 \pm 116$ & - & Bendle et al., 2017 \\
Buenos Aires Lake & $17,145 \pm 122$ & - & Bendle et al., 2017 \\
Buenos Aires Lake & $17,322 \pm 115$ & - & Bendle et al., 2017 \\
\hline
\end{tabular}

\section{Results}

\subsection{Glaciolacustrine sequences}

Several glaciolacustrine sequences were identified and analyzed in relation to their altitudes, varve spacing and geographic location. Four were described in the Argentine territory while other four sequences are reported from the Chilean territory (Fig. 2, Table 1). Argentine sequences are described from E to W; the Chilean from N to S. Grain sizes of the sampled varves vary significantly from 0 to $35 \%$ of sand. These variations were interpreted according to the lake dimensions, dynamics and distance from the glacial sources.
The samples were taken both in the Argentine (Fenix Chico River, Route 41 and Jeinimeni River) and in Chilean (Fachinal, Chacabuco Bridge) territories. Their compositions are dominated by clay and silt fractions.

\subsubsection{Fénix River terrace (top about $460 \mathrm{~m}$ above MSL)}

On the way from Perito Moreno to Los Antiguos (Fig. 3), the route 43 runs close to the headlands of the Fenix River. This terrace is about $460 \mathrm{~m}$ over MSL and corresponds to the former headlands of the Deseado River watershed. Presently, it is the continental divide between the Atlantic and Pacific watersheds. The outcrop is very small; a till is

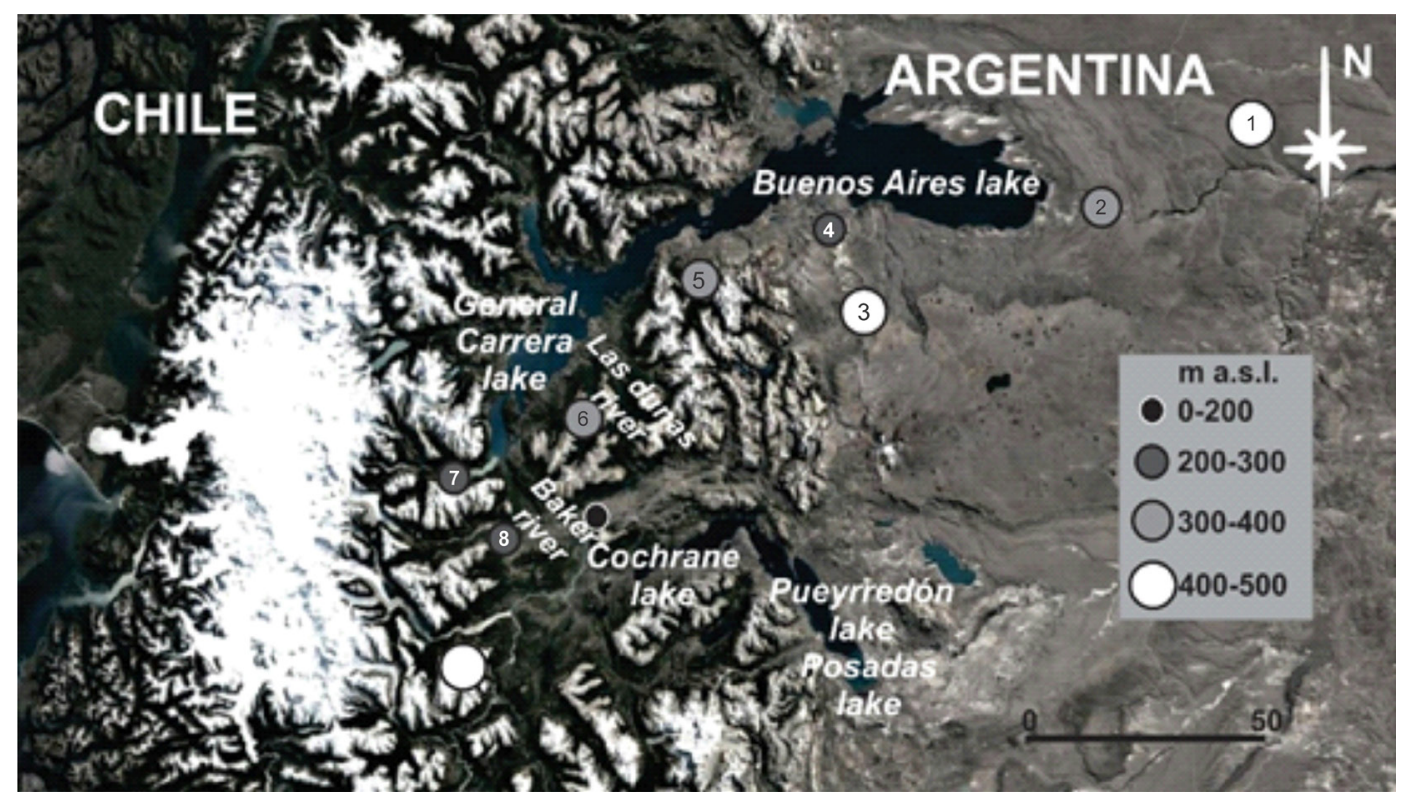

FIG. 2. Locations of the sedimentary sequences described in the text. Legends indicate the top altitudes (m above MSL) of the glaciolacustrine sequences, and referred to in table 1. Circles without numbers were mapped but not included in the report. 


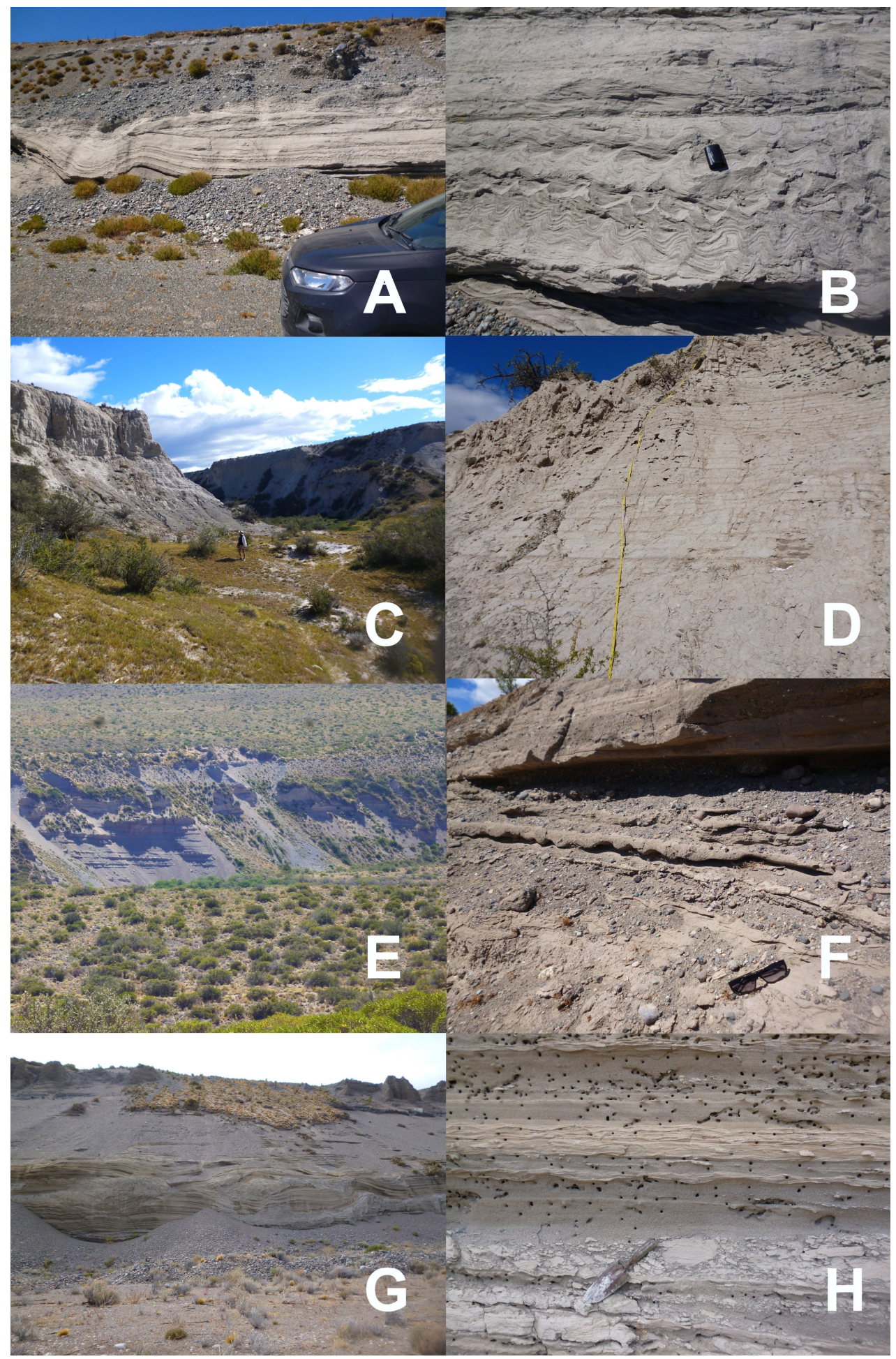

FIG. 3. Argentine glaciolacustrine sequences. A. Fénix River headlands. B. Detail of the convoluted level. C. headlands of Buenos Aires Lake. D. Detail. E. Glaciolacustrine terrace at route 41. F. Detail. G. Sequence outcropping at the eastern cliffs of the Jeinimeni River; H. Detail. 
outcropping at the base of the profile (Fig. 3A-B). On top of this sequence convolute bedding denotes physical perturbations (gravity-dominated phenomena are assumed) of the ancient lake during deposition.

\subsubsection{Lake Buenos Aires terrace (top about $354 \mathrm{~m}$ above MSL)}

This is the original sequence described by Caldenius (1932) where he counted and measured 530 varves. The deposit is $22.6 \mathrm{~m}$ thick with maximum varve thicknesses of $0.57 \mathrm{~m}$. The sample, collected from the middle of the sequence, is composed of silt and clay with small amounts of sand (Fig. 4); muscovite grains are dominant. The sequence was revisited and described in detail by Bendle et al. (2017). An ash layer intercalated in the sequence is assumed to belong to the Hudson Volcano $(170 \mathrm{~km}$ to the NW of this site) and dated in 17,378 \pm 118 cal yrs BP (Bendle et al., 2017). However, this tephra layer was not accepted as belonging to the Hudson Volcano (Bourgois et al., 2019). Five different sites from the Eastern Buenos Aires Lake sum $994 \pm 36$ varve-years (Bendle et al., 2017; Fig. 3C, D). Based on a 10-year moving average of the varve thickness, an average ice retreat of 5-10 m/yr occurred until 17,322 \pm 115 cal yrs BP that accelerated to $15-18 \mathrm{~m} / \mathrm{yr}$ to the end of the sequence (Bendle et al., 2017). Some of the assumptions to estimate these retreats were also questioned (Bourgois et al., 2019).

\subsubsection{Route 41 (South from Los Antiguos; top terrace about $514 \mathrm{~m}$ above $\mathrm{MSL}$ )}

About $13 \mathrm{~km}$ to the south of Los Antiguos village, route 41 is on top of a former lacustrine terrace. Further south, perched glacial features have been described in spatial relation to Monte Zeballos basalts (Lagabrielle et al., 2010). This glaciolacustrine terrace are composed of gravel (coarser than $3 \mathrm{~mm}$ ) alternating with sand and suggesting the coastal facies of the former lake (Fig. 3E, F). In a $1.5 \mathrm{~m}$ thick deposit 16 varves were counted (about $0.10 \mathrm{~m}$ each). In the sample, from the middle of the sequence, the silt fraction is dominant $(56 \%)$ with less proportions of clay (29\%) and sand (15\%; Fig. 4).

\subsubsection{Jeinimeni River (top terrace about $262 \mathrm{~m}$ above MSL)}

Between the Argentine Customs control and the Argentina-Chile boundary, the route runs close to a $20 \mathrm{~m}$ tall cliff along the Jeinimeni River valley. This valley was affected by glaciers and landslides flowing from the basalts of the Meseta del Lago Buenos Aires (Lagabrielle et al., 2010). Several outcrops of a former lake are accessible from the route

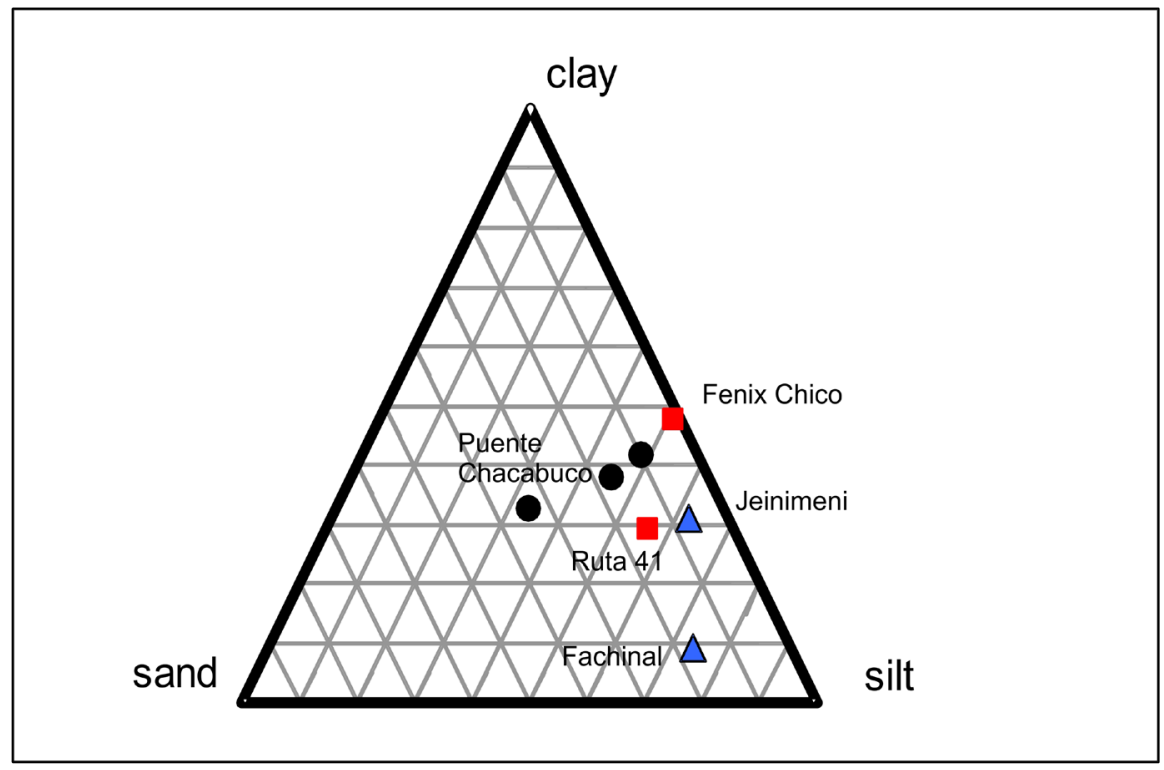

FIG. 4. Grain-size composition of the samples collected from the glaciolacustrine facies. Red squares are related to the Buenos Aires Lake, blue triangles to the General Carrera Lake, and black circles to the Chacabuco Bridge. 
(Fig. 3G, H). The sample collected was composed of silt (62\%), clay (30\%) and only $7 \%$ of sand.

\subsubsection{Fachinal terrace (top about $304 \mathrm{~m}$ above MSL)}

The Fachinal terrace is attached to the southern coast of the General Carrera Lake, Chile (Fig. 5A). Along the route at the southern shore of the lake, there are several outcrops. At the top of one of these sequences, there is a small quarry with varves of $1-2 \mathrm{~cm}$ thick (Fig. 5B). The glaciolacustrine deposit is close to the mountain and composed of coarser material: $73 \%$ silt, $16 \%$ sand and $9 \%$ of clay. Thirty $\mathrm{km}$ to the SW, the Las Dunas River delta has been subject to a particular analysis of its poorly sorted gravel spanning from well-rounded to subangular grain sizes, from cobbles (up to $200 \mathrm{~mm}$ ) to coarse sand (Bell, 2009). Two moraines are related to the modern delta; they were dated on $8.5 \pm 0.7$ kyrs BP (outer moraine) and $6.2 \pm 0.8$ kyrs BP (inner moraine; Douglass et al., 2005). At the southern coast of the General Carrera Lake two ancient shorelines were analyzed in terms of their altitude variations, indicating a tilting rate of $0.6 \mathrm{~m} / \mathrm{km}$ for the higher shoreline, and $0.45 \mathrm{~m} / \mathrm{km}$ at the lower coast (Turner et al., 2005).

\subsubsection{Bertrand Lake (about $236 \mathrm{~m}$ above MSL)}

Along the route from Bertrand Lake towards the south, there are saltuary outcrops with glaciolacustrine facies. Moraines close to Bertand Lake have been dated between 14,100 and 15,900 yrs BP (Thorndycraft et al., 2019). Varves are about $1 \mathrm{~cm}$ thick and composed of fine sediments (Fig. 5C, D).

\subsubsection{Borde Baker (about $230 \mathrm{~m}$ above MSL)}

At the western border of the Baker River, a huge landslide discovered a glaciolacustrine sequence close to the touristic resort Borde Baker. The landslide area, difficult to access, is about $200 \mathrm{~m}$ long and $30 \mathrm{~m}$ height. A glaciofluvial deposit is on top of the cliff (Fig. 5E, F).

\subsubsection{Chacabuco Bridge (about172 $\mathrm{m}$ above MSL)}

On the route from El Furioso to Cochrane, several glaciolacustrine sequences are outcropping. One of the characteristic of this area is the right angles of the Baker River in its flow towards the south, indicating a tectonic control. The section was described in detail by Turner et al. (2005) and recently reinterpreted by Thorndycraft et al. (2019). An ancient Chacabuco Paleolake was reported as older than the General
Carrera-Buenos Aires and Pueyrredon-Posadas systems, and at an altitude of $620 \mathrm{~m}$ above MSL (Glasser et al., 2016). At the place called Puente Chacabuco (Chacabuco Bridge), the outcrop is more than $400 \mathrm{~m}$ long and $8 \mathrm{~m}$ height. The thicknesses of the varves are of approximately $1 \mathrm{~m}$ each (Fig. $5 \mathrm{G}, \mathrm{H})$. Three layers were sampled at this site; they are composed of $32-47 \%$ of silt; $32-42 \%$ of clay and $9-34 \%$ of sand (Fig. 4). The samples from this outcrop are the coarser sampled with thicker varves.

\subsection{Altitude distribution}

At the Argentine side, the maximum altitude of the glaciolacustrine sequences diminishes towards the west. At the Chilean side, the altitudes of the former lake levels diminish northwards (Fig. 2). At the Argentine territory the altitudes are higher as the distances to the present lakes increase. The highest levels are at about $500 \mathrm{~m}$ over MSL suggesting the maximum extension of the largest paleolake.

\subsection{Landscape evolution}

The decrease in the water level of this great lake caused the formation of several Gilbert-type deltas in relation to each level (Bell, 2009). Beach plains also formed attached to the most modern delta (Bell, 2009). The tilting of the shoreline deposits of the General Carrera Lake was analyzed exclusively in relation to the distance from the glacier center (Turner et al., 2005).

Three major glacial valleys converge to the General Carrera-Buenos Aires Lake (Fig. 6). Another glacial valley has drained towards the Cochrane-PueyrredonPosadas lacustrine complex (Fig. 6). Glaciolaustrine sequences of both lacustrine complexes remain at the eastern margin of the paleolake (Ton-That et al., 1999; Hein et al., 2009, 2010; Horta et al., 2011; Isla et al., 2015; Bendle et al., 2017).

According to the ash layer recognized close to the top of the sequences at lake Buenos Aires terrace, dated in $17,378 \pm 118 \mathrm{cal}$ yrs BP, and assumed to belong to Hudson volcano (known as Ho), the receding rates of the glaciers were moderate $(5-10 \mathrm{~m} / \mathrm{yr})$ before the eruption and accelerated to $15-18 \mathrm{~m} / \mathrm{yr}$ after that age (Bendle et al., 2017). These watersheds were also subject to intense faulting derived from the interactions of the subduction of the active ridge since $3 \mathrm{Ma}$ to Present (Lagabrielle et al., 2000, 2004). 


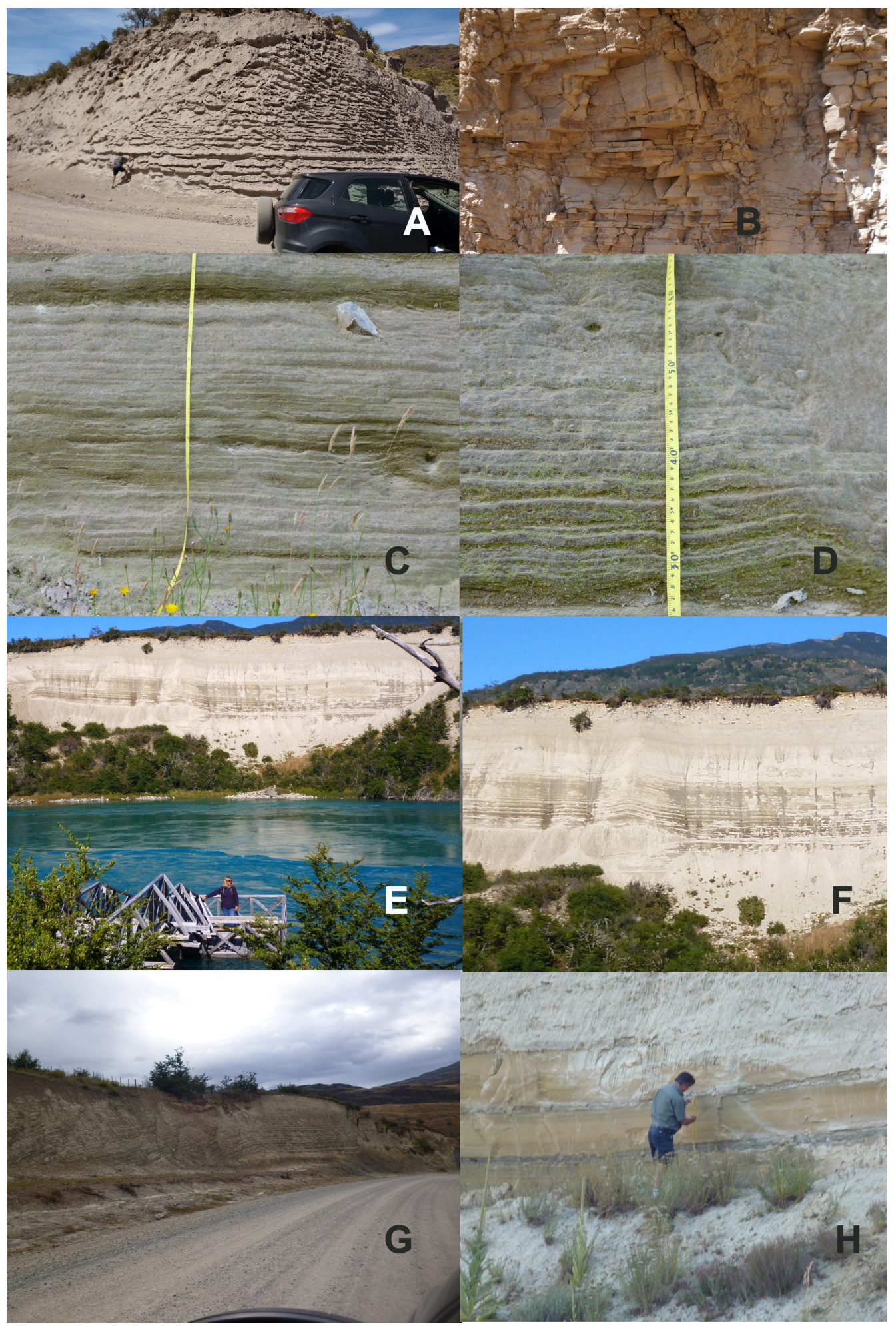

FIG. 5. Chilean glaciolacustrine sequences. From N to S: A. Fachinal; B. Detail of the varves; C. Bertrand Lake; D. Detail; E. Baker River profile; F. Detail; G. Chacabuco River; H. Detail. 

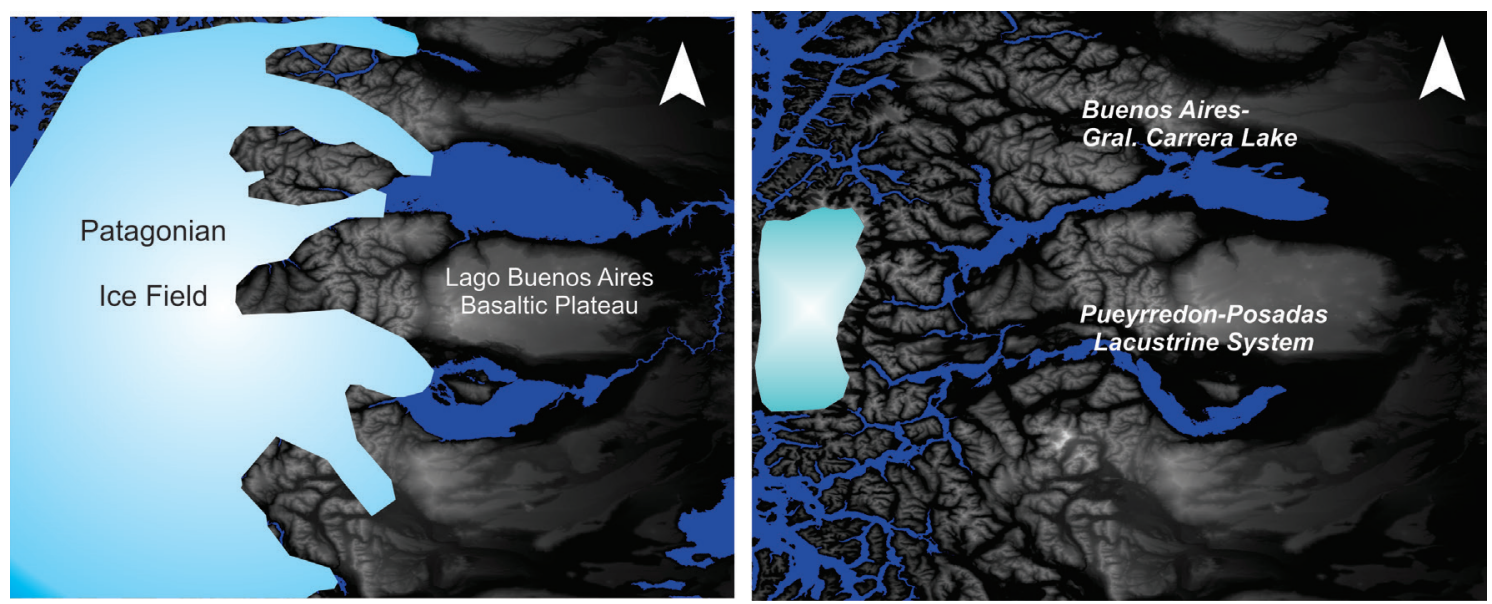

FIG. 6. Sketch map of the evolution of the Northern Patagonian Ice Field and the associated glaciolacustrine lakes. A. The extension of former lakes during the Pleistocene was located at the $500 \mathrm{~m}$ over MSL. B. Present conditions for the approximately $230 \mathrm{~m}$ height of the Buenos Aires-General Carrera Lake and the Pueyrredon-Posadas lacustrine complex (modified after Glasser et al., 2004, 2005; Bendle et al., 2017).

Approximately $100 \mathrm{~km}$ to the north of the Buenos Aires-General Carrera Lake, the evolution of the Castor Lake (45.6 $\mathrm{S} ; 71.8^{\circ} \mathrm{W} ; 699 \mathrm{~m}$ above MSL) was analyzed by the means of a 15.4 m core extracted from a depth of $46 \mathrm{~m}$ (Van Daele et al., 2016). The core contained two ash layers assumed to belong to the Hudson Volcano (Ho and H2). Sedimentation rates were estimated in approximately $0.3 \mathrm{~cm} / \mathrm{yr}$ during the interval 20-18 cal kyrs BP diminishing to $0.036-0.051 \mathrm{~cm} / \mathrm{yr}$ for the most recent interval (16.75 kyrs BP to present; Van Daele et al., 2016).

\section{Discussion}

Variations in lake levels can be assigned to climatic changes, but also to variations in the watersheds triggered by tectonic movements, fluvial captures or volcanic activity (Isla et al., 2015; Martinod et al., 2016). Palinological studies in some of the piedmont lakes in the Patagonian Andes indicate significant variations of the westerly winds that could led to dessication intervals and increments of their strength between 11,200 and 4,500 years BP suggesting a broadening of the wind belt (Van Daele et al., 2016). The more complete varve sequence considered in this study (Eastern Lake Buenos Aires terrace), however, is only reporting approximately 994 years. For the Eastern Buenos Aires Lake, several lava deposits of Upper Pleistocene age were reported leading to the deactivation of the Deseado River (Ton-That et al., 1999; Kaplan et al., 2004). The retreat of the ice lobes about $10 \mathrm{kyrs}$ BP was proposed for the activation of the Baker River and the reversal of the drainage of the lacustrine system towards the Pacific Ocean (Isla et al., 2015). During the interval of this drainage reversal, several paleolakes (Cisnes-Ñirehuao, Deseado, Tranquilo, Colonia, Cochrane-PueyrredonChacabuco) were defined and mapped (Davies et al., 2020). A temporal reversal via the Bayo River was proposed (Martinod et al., 2016) operating during the interval between 15,000 and 12,600 years BP (Bourgois et al., 2019). Catastrophic GLOF events have also occurred at this watershed (Ulloa et al., 2018; Thorndycraft et al., 2019; Bañales-Seguel et $a l ., 2020)$. The reactivation of tectonic faults induced by the subduction of the Chile Ridge, mostly related to the Cachet and Exploradores fault zones, can explain these recent geomorphological changes (Agurto-Detzel et al., 2014; Georgieva et al., 2016). An isostatic rebound was proposed to explain the altitudes of the Las Dunas River terraces (Bourgois et al., 2016; Martinod et al., 2016), disregarding the tectonic tilting (Turner et al., 2005). These tectonic processes were reported for the Meseta del Lago Buenos Aires where an inversion of a paleo-piedmont occurred about $3 \mathrm{Ma}$ (Lagabrielle et al., 2010). The basalts of Meseta del Lago Buenos Aires and Meseta de Chile Chico are genetically related to a subducted segment of the Chile Ridge, enclosed between the Tres Montes and Esmeralda fracture zones (Lagabrielle 
et al., 2004). Tilting effects were also reported for the former shorelines of ice-dammed lakes at the Magellan Strait region (McCulloch et al., 2005). The isostatic rebound of the Northern Patagonian Ice Field (NPIF) should be minimized considering that it was neglected in Tierra del Fuego, where glaciations were assumed to be more extended than at the NPIF (Mörner, 1991).

The basaltic extrusions and intrusions occurred during the last $3 \mathrm{Ma}$ conditioned the morphology where the glaciers were limited to flow (Lagabrielle et al., 2010). Lava deposits of Upper Pleistocene age were reported to the east of Buenos Aires Lake (Ton-That et al., 1999). These deposits caused that some Argentine rivers (Pinturas, Deseado) diminished significantly their watersheds. As consequence the Baker River incorporated stepwise several lakes in its watershed about $10 \mathrm{kyrs}$, and led to the progradation of its delta system close to Caleta Tortel (Isla et al., 2015). An evolution model of these steps in the retreat of the ice fronts and lake level drops has been proposed based on digital elevation models (Fig. 7). A fault oriented N-S was mapped at the Eastern border of the present NPIF (Cachet Fault). This block is assumed to move towards the north (Georgieva et al., 2016). The final stages of the drainage of the General Carrera-
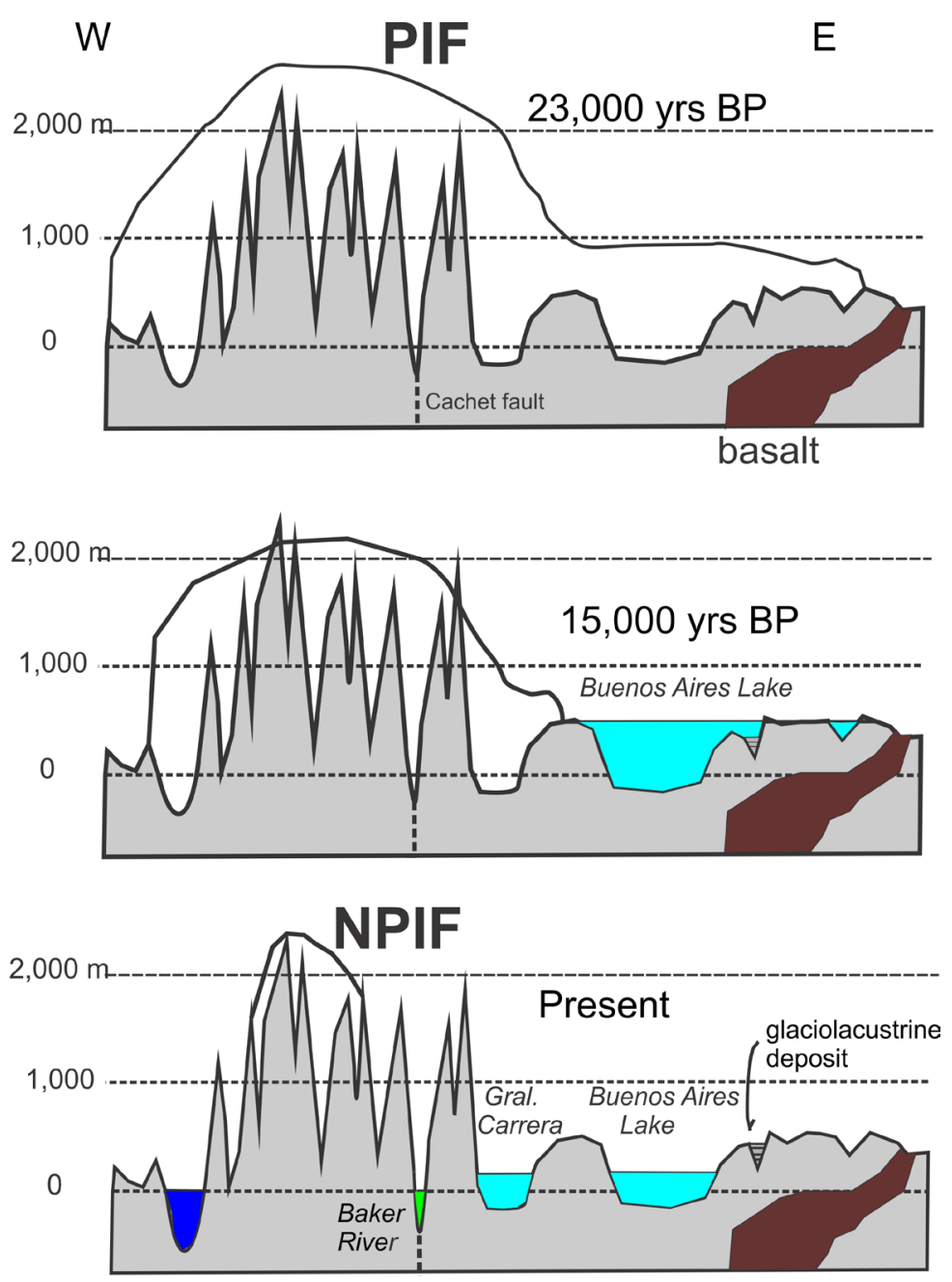

FIG. 7. Evolution model of the ice-front retreatments of the original Patagonian Ice Field (PIF), lake-level variations, blocking of the flow towards the East (Fenix, Pinturas, Deseado rivers) and the glaciolacustrine-deposits at the Buenos Aires Lake (modified from Ton-That et al., 1999, and Georgieva et al., 2016). NPIF: Northern Patagonian Ice Field. 
Buenos Aires Lake system has been reported with the catastrophic flooding of the Baker River about 10,000 yrs BP (Thorndycraft et al., 2019; Davies et al., 2020). Other glacial lake outburst floods (GLOFs) have occurred recently along the Baker (Ulloa et al., 2018) and Exploradores rivers (Bañales-Seguel et al., 2020). Recent GLOFs are of special concern in relation to the historic mountain-glacier contributions to the sea level (Zemp et al., 2019)

Several glaciolacustrine sequences have been reported along the Southern Andes of Patagonia and Tierra del Fuego from 40 to $54^{\circ} \mathrm{S}$, although the altitudes and ages of these paleolakes are not similar. Some of these sequences are suggesting reversals in the drainage patterns:

a. The Aluminé and Moquehue lakes ( $38^{\circ} 55^{\prime} \mathrm{S}$;

Fig. 1) were though to drain towards the northeast to the Pacific Ocean by the watershed of the Biobio River. After the eruption of the Sollipulli Volcano about 2,900 \pm 60 yrs BP, the Alumine Lake is draining towards the SE (Isla et al., 2019). The Aluminé River is flowing to the Collón Cura, Limay and Negro rivers, towards the Atlantic Ocean.

b. The great Elpalafquen paleolake $\left(41^{\circ} \mathrm{S}\right.$; Fig. 1$)$ comprises several modern piedmont lakes (Nahuel Huapi, Gutiérrez, Mascardi, Fonck and Steffen, and the small shallow lakes Cari Lafquen Grande and Cari Lafquen Chica). This great lake originally drained towards the Atlantic Ocean via the Limay River. Afterwards, it began to flow to the Pacific Ocean via the Manso River about 13,200 yrs BP (Del Valle et al., 2007; Davies et al., 2020). At the area between Pilcaniyeu and Maquinchao, east of the present piedmont lakes, two dacitic tephras indicate that this ancient lake remained between 13,800 and 11,200 yrs BP (Tatur et al., 2002).

c. Another paleolake, the Caldenius (47 $50^{\prime} \mathrm{S}$; Fig. 1) comprised the Belgrano, Azara, Mogote, Nansen, Volcán and Burmeister lakes, of former Atlantic destination that opened towards the Pacific Ocean about 10,000 yrs BP (Del Valle et al., 2007). Two lakes, related to present Belgrano and Burmeister lakes, of Upper Pleistocene age (about 31,200 yrs BP) were positioned $880 \mathrm{~m}$ above MSL. Between 11,371 and 10,819 yrs BP, a lake close to Northern Belgrano Lake, reached levels of 900-920 m above MSL. About 6,900 yrs BP the level dropped to split into two-lake settings separated by moraines (Horta et al., 2017). d. The Great Tehuelche paleolake (51 $50^{\prime} \mathrm{S}$; Fig. 1) occupied the area of Torres del Paine. It comprised several of present lakes: Nordenskjold, Pehoe, Sarmiento, del Toro and Porteño. Between 24,291 and 17,500 yrs BP the paleolake level was between 260 and $240 \mathrm{~m}$ above MSL (Solari et al., 2012). Between 14,800 and 12,600 there was a glacial readvance while the lake was at an altitude of 165-150 m above MSL (Solari et al., 2012). During that interval several temporal lakes were recognized (Blanca, Skyring, Otway; Davies et al., 2020). 7,113 years ago the area of the former Great Tehuelche Lake began to drain towards the Pacific Ocean, via the Seno Ultima Esperanza (Solari et al., 2012). Two glaciolacustrine terraces were discriminated along the Almirante Montt Gulf: the oldest (150-125 m height) attached to the Arauco Morainic Complex (Arauco paleolake), and the modernmost ( $30 \mathrm{~m}$ altitude), attached to the present oceanic coast (Sagredo et al., 2011). Between 1,200 and 200 years ago the del Toro Lake was at altitudes about $80 \mathrm{~m}$ above present MSL (Solari et al., 2010).

e. Another extended piedmont lake has occupied the central portion of the Magellan Strait and Bahía Inútil (38 $\left.55^{\prime} \mathrm{S}\right)$ during the end of the Pleistocene (MacCulloch et al., 2005). This paleolake Magallanes-Bahía Inútil, occupying both glacial valleys, persisted about $15,000 \mathrm{yrs}$ BP (Davies et al., 2020). Two glacial advances were discriminated in relation to the Mount Reclus eruption event.

f. In the Grande Island of Tierra del Fuego, changes in the glaciolacustrine watersheds have also taken place. The ancient paleolake called Fueguino Lake (540'' S; Fig. 1), comprising the Yehuin, Chepelnut, Yakush and Penny lakes, was draining towards the Atlantic Ocean during the Upper Pleistocene (Del Valle et al., 2007). The Fagnano Lake captured this watershed after 7,800 yrs BP, and therefore today it is draining towards the Pacific Ocean, via Seno Almirantazgo Channel (Del Valle et al., 2007).

The comparisons between the altitudes and ages of these Upper-Pleistocene glaciolacustrine sequences should be analyzed considering also the differential tectonic trends and the distance to volcanic features (Ton-That et al., 1999; Lagabrielle et al., 2010; Georgieva et al., 2016). Glacio-isostatic 
rebounds should be disregarded as a major effect on topographic variations in comparison to the tectonic and volcanic-triggered effects (lopolites, laccolites). However, these comparisons should consider other issues as watershed changes, precipitation variations, local climate and wind-induced lake dynamics.

\section{Conclusions}

1. The great Buenos Aires-General Carrera paleolake reversed its flow at the same time that its level dropped from approximately 500 to $230 \mathrm{~m}$ over mean sea level about 12, 800 yrs BP. This altitudinal difference should be interpreted considering climatic changes, local tectonic effects (faults, including tilting) probably induced by the subduction of the Chile Ridge.

2. The geomorphological changes that affected this former glacial valley transformed it into a great lacustrine basin and led to the capture of another glacial valley discharge occupied today by the Cochrane, Pueyrredon and Posadas lakes.

3. As the drainage of the glacial valleys reversed their discharges direction towards the Pacific Ocean (via the Baker River), the rivers flowing towards the Atlantic Ocean (Deseado, Pinturas) had experienced significant diminution on their discharges since 12,800 yrs BP.

4. Much of these geomorphologic changes should be also assigned to the reactivation of faults caused by the subduction of the active Chile ridge at the Triple Junction region, and the volcanic activity, occurred since $3 \mathrm{Ma}$ to Present. Therefore, it is not recommended to extrapolate the timing of the geomorphological variations of a region assigned to climatic changes without considering other factors (tectonic, volcanic activity, lake dynamics, watershed changes).

\section{Acknowledgements}

Authors are indebted to the owners of the Estancia at the headlands of the Fénix River. Two anonymous reviewers collaborate with significant contributions. The editor suggested significant improvements.

\section{References}

Agurto-Detzel, H.; Rietbrock, A.; Bataille, K.; Miller, M.; Iwamori, H.; Priestley, K. 2014. Seismicity distribution in the vicinity of the Chile Triple Junction, Aysén
Region, southern Chile. Journal of South American Earth Sciences 51: 1-11. doi: 10.1016/j.jsames.2013.12.011.

Bañales-Seguel, C.; Salazar, A.; Mao, L. 2020. Hydromorphological characteristics and recent changes of a nearly pristine river system in Chilean Patagonia: The Exploradores river network. Journal of South American Earth Sciences 98: 102444. doi: 10.1016/j. jsames.2019.102444.

Bell, C.M. 2009. Quaternary lacustrine braid deltas on Lake General Carrera in southern Chile. Andean Geology 36 (1): 51-65. doi: 10.5027/andgeoV36n1-a04.

Bendle, J. M.; Palmer, A.P.; Thorndycraft, V. R.; Matthews, I.P. 2017. High-resolution chronology for deglaciation of the Patagonian Ice Sheet at Lago Buenos Aires $\left(46.5^{\circ} \mathrm{S}\right)$ revealed through varve chronology and Bayesian age modeling. Quaternary Sciences Reviews 177: 314-339.

Beraza, L.A.; Vilas, J.F.A. 1990. Palaeomagnetic data from Late Glacial glaciolacustrine sediments at Rio Corintos, Chubut, Argentina. Physics of the Earth and Planetary Interiors 64: 111-120.

Boutonnet, E.; Arnaud, N.; Guivel, C.; Lagabrielle, Y.; Scalabrino, B.; Espinoza, F. 2010. Subduction of the South Chile active spreading ridge: A $17 \mathrm{Ma}$ to 3 Ma magmatic record in central Patagonia (western edge of Meseta del Lago Buenos Aires, Argentina). Journal of Volcanology and Geothermal Research 189: 319-339.

Broecker, W.S. 1998. The end of present Interglacial: How and when? Quaternary Science Reviews 17: 689-694.

Bourgois, J.; Cisternas, M.E.; Braucher, R.; Bourlès, D.; Frutos, J. 2016. Geomorphic Records along the General Carrera (Chile)-Buenos Aires (Argentina) Glacial Lake $\left(46^{\circ}-48^{\circ} \mathrm{S}\right)$, Climate Inferences, and Glacial Rebound for the Past 7-9 ka. Journal of Geology 124: 27-53.

Bourgois, J.; Guivel, C.; Lagabrielle, Y.; Calmus, T.; Boulegue, J.; Daux, V. 2000. Glacial-interglacial trench supply variation, spreading-ridge subduction, and feedback controls on the Andean margin development at the Chile triple junction area $\left(45-48^{\circ} \mathrm{S}\right)$. Journal of Geophysical Research 105: 8355-8386.

Bourgois, J.; Cisternas, M.E.; Frutos, J. 2019. Comments on: "Glacial lake evolution and Atlantic-Pacific drainage reversals during deglaciation of the Patagonia ice sheet" by Thorndycraft et al. (Quaternary Science Reviews 203: 102-127). Quaternary Science Reviews 213: $167-170$.

Caldenius, C. 1932. Las Glaciaciones Cuaternarias en Patagonia y Tierra del Fuego. Ministerio de 
Agricultura de la Nación. Dirección General de Minas y Geología 95 (1): 148 p. Buenos Aires.

Clague, J.J.; Barendregt, R.W.; Menounos, B.; Roberts, N. J.; Rabassa, J.; Martínez, O.; Ercolano, B.; Corbella, H.; Hemming, S.R. 2020. Pliocene and Early Pleistocene glaciation and landscape evolution on the Patagonian Steppe, Santa Cruz province, Argentina. Quaternary Science Reviews 227: 105992.

Davies, B.J.; Darvill, C.M.; Lovell, H.; Bendle, J.M.; Dowdeswell, J.M.; Fabel, D.; Garcia, J.L.; Geiger, A.; Glasser, N.F.; Gheorghiu, D.M.; Harrison, S.; Hein, A.S.; Kaplan, M.R.; Martin, J.R.V.; Mendelova, M.; Palmer, A.; Pelto, M.; Rodés, A.; Sagredo, E.A.; Smedley, R.; Smellie, J.R.; Thondycraft, V.R. 2020. The evolution of the Patagonian Ice Sheet from $35 \mathrm{ka}$ to the present day (PATICE). Earth-Science Reviews 204: 103152. doi: 10.1016/j.earscirev.2020.103152.

Del Valle, R.A.; Tatur, A.; Rinaldi, C.A. 2007. Cambios en lagos y circulación fluvial vinculados al calentamiento climático del Pleistoceno tardío-Holoceno temprano en Patagonia e Isla 25 de Mayo, Islas Shetland del Sur, Antártida. Revista de la Asociación Geológica Argentina 62 (4): 618-626.

Douglass, D.C.; Singer, B.S.; Kaplan, M.R.; Ackert, R.P.; Mickelson, D.M.; Caffee, M.W. 2005. Evidence of early Holocene glacial advances in southern South America from cosmogenic surface-exposure dating. Geology 33 (3): 237-240.

Fidalgo, F.; Riggi, J.C. 1965. Los rodados patagónicos en la Meseta del Guenguel y alrededores (Santa Cruz). Revista de la Asociación Geológica Argentina 20 (3): 273-325.

Folguera, A.; Ramos, V.A. 2002. Los efectos producidos por la aproximación, colisión y subducción de dorsales pacíficas en los Andes Patagónicos. Acta Geológica Hispánica 37 (4): 329-353.

Georgieva, V.; Melnick, D.; Schildgen, T.F.; Ehlers, T.A.; Lagabrielle, Y.; Enkelmann, E.; Strecker, M.F. 2016. Tectonic control on rock uplift, exhumation, and topography above an oceanic ridge collision: Southern Patagonian Andes (47 S), Chile. Tectonics 35 (6): 1317-1341. doi: 10.1002/2016TC004120.

Ghiglione, M.C.; Sue, C.; Ramos, M.E.; Tobal, J.E.; Gallardo, R.E. 2016. The relation between Neogene denudation of the Southernmost Andes and sedimentation in the offshore Argentine and Malvinas basins during the opening of the Drake Passage. In Evolution of the Southernmosrt Andes (Ghiglione, M.C.; editor). Springer Earth System Sciences: 109-135.
Glasser; N.F.; Harrison, S.; Winchester, V.; Aniya, M. 2004. Late Pleistocene and Holocene palaeoclimate and glacier fluctuations in Patagonia. Global and Planetary Change 43: 79-101.

Glasser, N.F.; Jansson, K.N.; Harrison, S.; Rivera, A. 2005. Geomorphological evidence for variations of the North Patagonian Icefield during the Holocene. Geomorphology 71: 263-267.

Glasser, N.F.; Jansson, K.N.; Duller, G.A.T.; Singarayer, J.; Holloway, M.; Harrison, S. 2016. Glacial lake drainage in Patagonia (13-8 kyr) and response of the adjacent Pacific Ocean. Scientific Reports 6: 21064. doi: 10.1038/srep21064.

Guivel, C.; Lagabrielle, Y.; Bourgois, J.; Maury, R.C.; Fourcade, S.; Martin, H.; Arnaud, N. 1999. New geochemical constraints for the origin of ridgesubduction-related plutonic and volcanic suites from the Chile Triple Junction (Taitao Peninsula and site 862, LEG ODP141 on the Taitao Ridge). Tectonophysics 311: 83-111.

Hein, A.S.; Hulton, N.R.J.; Dunai, T.J.; Schnabel, C.; Kaplan, M.R.; Naylor, M.; Xu, S. 2009. Middle Pleistocene glaciation in Patagonia dated by cosmogenic-nuclide measurements on outwash gravels. Earth and Planetary Science Letters 286: 184-197.

Hein, A.S.; Hulton, N.J.R.; Dunai, T.J.; Sugden, D.E.; Kaplan, M.R.; Xu, S. 2010. The chronology of the Last Glacial Maximum and deglacial events in central Argentine Patagonia. Quaternary Science Reviews 29: 1212-1227.

Horta, L.R.; Georgieff, S.M.; Console-Gonella, C.A.; Bunelli, J.; Aschero, C.A. 2011. Registros de fluctuaciones paleobatimétricas del sistema lacustre Pueyrredon-Posadas-Salitroso durante el Pleistoceno Tardío?-Holoceno Temprano, noroeste de Santa Cruz, Argentina. Serie Correlación Geológica 27 (2): 100-109.

Horta, L.R.; Georgieff, S.M.; Aschero, C.A.; Goñi, R.A. 2017. Paleolacustrine records from Late Pleistocene e Holocene in the Perito Moreno National Park, Argentinian Patagonian Andes. Quaternary International 436: 8-15.

Isla, F.I.; Espinosa, M.A.; Bujalesky, G. 2010. Summer stratification of Andean lakes of Patagonia and Tierra del Fuego: Global warming or ENSO effects? Revista Geográfica del Sur 1 (2): 55-71.

Isla, F.; Espinosa, M.; Iantanos, N. 2015. Evolution of the Eastern flank of the North Patagonian Ice Field: The deactivation of the Deseado River (Argentina) and the activation of the Baker River (Chile). Zeitschrift für Geomorphologie 59 (1): 119-131. 
Isla, F. I.; Quezada Flory. J.; Ramírez, C. 2019. La Zona Costera en Chile: Adaptación y Planificación para la Resiliencia (Martínez, C.; Hidalgo, R.; Henríquez, C.; Arenas, F.; Rangel, N.; Contreras-López, M.; editores). Serie GEOlibro $\mathrm{N}^{\circ} 31$, Instituto de Geografía, Pontificia Universidad Católica de Chile, Santiago: 123-131.

Kaplan, M.R.; Douglas, D.C.; Singer, B.S.; Ackert, R.P.; Caffee, M.W. 2004. Cosmogenic nuclide chronology of pre-last glacial maximum moraines at Lago Buenos Aires, $46^{\circ} \mathrm{S}$, Argentina. Quaternary Research 63: 301-315.

Lagabrielle, Y.; Guivel, C.; Maury, R. C.; Bourgois, J.; Fourcade, S.; Martin, H. 2000. Magmatic-tectonic effects of high thermal regime at the site of active ridge subduction: the Chile Triple Junction model. Tectonophysics 326: 255-268.

Lagabrielle, Y.; Suárez, M.; Rosello, E.A.; Herail, G.; Regnier, G.; Martinod, J.; De la Cruz, R. 2004. Neogene to Quaternary tectonic evolution of the Patagonian Andes at the latitude of the Chile Triple Junction. Tectonophysics 385: 211-241.

Lagabrielle, Y.; Scalabrino, B.; Suárez, M.; Ritz, J.F. 2010. Mio-Pliocene glaciations of Central Patagonia: New evidences and tectonic implications. Andean Geology 37: 276-299.

Martinod, J.; Pouyaud, B.; Carretier, S.; Guillaume, B.; Hérail, G. 2016. Geomorphic records along the General Carrera (Chile)-Buenos Aires (Argentina) Glacial Lake $\left(46^{\circ}-48^{\circ} \mathrm{S}\right)$, Climate Inferences, and Glacial Rebound for the Past 7-9 ka: A discussion. The Journal of Geology 124: 631-635.

Mazzoni, E.; Rabassa, J. 2010. Inventario y clasificación de manifestaciones basálticas de Patagonia mediante imágenes satelitales y SIG, Provincia de Santa Cruz. Revista de la Asociación Geológica Argentina 66 (4): 608-618.

McCulloch, R.D.; Bentley, M.J.; Purves, R.S.; Hulton, N. R.J.; Sugden, D.E.; Clapperton, C.M. 2000. Climatic inferences from glacial and palaeoecological evidence at the last glacial termination, southern South America. Journal of Quaternary Science 15(4): 409-417.

McCulloch, R.D.; Bentley, M.J.; Tipping, R.M.; Clapperton, C.M. 2005. Evidence for Late-glacial ice dammed lakes in the central Strait of Magellan and Bahía Inútil, Southernmost South America. Geografiska Annaler 87 A: 335-362.

Mörner, N. 1991. Holocene sea level changes in the Tierra del Fuego region. Boletin IG-USP, Sao Paulo, Special Publication 8: 133-151.
Panza, J.L.; Nullo, F.E. 1994. Mapa geológico de la Provincia de Santa Cruz, República Argentina. Escala 1:750.000, Secretaría de Minería, Dirección Nacional del Servicio Geológico, Buenos Aires.

Ranero, C.R.; Von Huene, R.; Weinrebe, W.; Reichert, Ch. 2006. Tectonic processes along the Chile convergent margin. In The Andes. Active subduction orogeny (Oncken, O.; Chong, G.; Franz, G.; Giese, P.; Götze, H.J.; Ramos, V.A.; Strecker, M.; Wigger, P.; editors). Springer 91: $121 \mathrm{p}$.

Richter, A.; Hormaechea, J.L.; Dietrich, R.; Perdomo, R.; Fritsche, M.; Del Cogliano, D.; Liebshc, G.; Mendoza, L. 2010. Lake-level variations of Lago Fagnano, Tierra del Fuego: observations, modelling and interpretation. Journal of Limnology 69 (1): 29-41.

Russo, R.M.; VanDecar, J.C.; Comte, D.; Mocanu, V.I.; Gallego, A.; Murdie, R.E. 2010. Subduction of the Chile Ridge: Upper mantle structure and flow. GSA Today 20 (9): 4-10. doi: 10.1130/GSATG61A.1.

Sagredo, E.A.; Moreno, P.I.; Villa-Martínez, R.; Kaplan, M.R.; Kubik, P.W.; Stern, C.R. 2011. Fluctuations of the Última Esperanza ice lobe $\left(52^{\circ} \mathrm{S}\right)$, Chilean Patagonia, during the last glacial maximum and termination 1 . Geomorphology 125: 92-108.

Solari, M.A.; Hervé, F.; Le Roux, J.P.; Airo, A.; Sial, A.N. 2010. Paleoclimatic significance of lacustrine microbialites: A stable isotope case study of two lakes at Torres del Paine, southern Chile. Palaeogeography, Palaeoclimatology, Palaeoecology 297: 70-82.

Solari, M.A.; Le Roux, J.P.; Hervé, F.; Airo, A.; Calderón, M. 2012. Evolution of the Great Tehuelche Paleolake in the Torres del Paine National Park of Chilean Patagonia during the Last Glacial Maximum and Holocene. Andean Geology 39 (1): 1-21. doi: 10.5027/ andgeoV39n1-a01.

Tatur, A.; Del Valle, R.; Bianchi, M.M.; Outes, V.; Villarosa, G.; Niegodzisz, J.; Debaene, G. 2002. Late Pleistocene palaeolakes in the Andean and ExtraAndean Patagonia at mid-latitudes of South America. Quaternary International 89: 135-150.

Thorndycraft, V.R.; Bendle, J.M.; Benito, G.; Davies, B. J.; Sancho, C.; Palmer, A.P.; Fabel, D.; Medialdea, A.; Martin, J.R.V. 2019. Glacial lake evolution and Atlantic-Pacific drainage reversals during deglaciation of the Patagonian Ice Sheet. Quaternary Science Reviews 203: 102-127.

Turner, K.J.; Fogwill, C.J.; McCulloch, R.D.; Sugden, D.E. 2005. Deglaciation of the Eastern flank of the North Patagonian Icefield and associated 
continental-scale lake diversions, Geografiska Annaler 87: 363-374.

Ton-That, T.; Singer, B.; Mörner, N.A.; Rabassa, J. 1999. Datación de lavas basálticas por ${ }^{40} \mathrm{Ar} /{ }^{39} \mathrm{Ar}$ y geología glacial de la región de Lago Buenos Aires, provincia de Santa Cruz, Argentina. Revista de la Asociación Geológica Argentina 54 (4): 333-352.

Ulloa, H.; Mazzorana, B.; Batalla, R.J.; Jullian, C.; Iribarren-Anacona, P.; Barrientos, G.; Reid, B.; Oyarzún, C.; Schaefer, M.; Iroumé, A.; 2018. Morphological characterization of a highly-dynamic fluvial landscape: The River Baker (Chilean Patagonia). Journal of South American Earth Sciences 86: 1-14.

Van Daele, M.; Bertrand, S.; Meyer, I.; Moernaut, J.; Vandoorne, W.; Siani, G.; Tanghe, N.; Ghazoui,
Z.; Pino. M.; Urrutia, R.; De Batist, M. 2016. Late Quaternary evolution of Lago Castor (Chile, $45.6^{\circ} \mathrm{S}$ ): Timing of the deglaciation in northern Patagonia and evolution of the southern westerlies during the last 17 kyr. Quaternary Science Reviews 133: 130-146.

Villa-Martínez, R.; Moreno, P.I.; Valenzuela, M.A. 2012. Deglacial and postglacial vegetation changes on the eastern slopes of the central Patagonian Andes $\left(47^{\circ} \mathrm{S}\right)$. Quaternary Science Reviews 32: 86-99.

Zemp, M.; Huss, M.; Thibert, E.; Eckert, N.; Mc Nabb, R.; Huber, J.; Barandun, M.; Machguth, H.; Nussbaumer, S.U.; Gärtner-Roer, I.; Thomson, L.; Paul, F.; Maussion, F.; Kutuzov, S.; Gogley, J.G. 2019. Global glacier mass changes and their contributions to sea-level rise from 1961 to 2016. Nature 568: 382-386.

Manuscript received: March 1, 2018; revised/accepted: May 4, 2020; available online: September 30, 2020. 